\title{
Triterpenes and Acylglycerols from Canarium ovatum
}

\author{
Consolacion Y. Ragasa ${ }^{1,2^{*}}$, Oscar B. Torres ${ }^{2}$, Jessa Mae P. Gutierrez ${ }^{2}$, Hannah Patricia Beatriz C. Kristiansen ${ }^{2}$, and \\ Chien-Chang Shen ${ }^{3}$ \\ ${ }^{1}$ Chemistry Department, De La Salle University Science \& Technology Complex Leandro V. Locsin Campus, Biñan City, Laguna 4024, Philippines \\ ${ }^{2}$ Chemistry Department, De La Salle University, 2401 Taft Avenue, Manila 1004, Philippines. ${ }^{3}$ National Research Institute of Chinese Medicine, 155-1, Li- \\ Nong St., Sec. 2, Taipei 112, Taiwan.
}

\section{ARTICLE INFO \\ Article history: Received on: 19/01/2015 Revised on: 09/02/2015 Accepted on: 27/02/2015 Available online: 27/04/2015}

Key words: Canarium ovatum, Burseraceae, $\beta$ amyrin, $\alpha$-amyrin, epi- $\beta$ amyrin, epi- $\alpha$-amyrin, epilupeol, $\beta$-carotene, lutein, triacylglycerols, 1,2dioleylglycerol

\begin{abstract}
Chemical investigations of the dichloromethane extracts of the leaves of Canarium ovatum Engl. afforded $\beta$ amyrin (1a), $\alpha$-amyrin (1b), epi- $\beta$-amyrin (2a), epi- $\alpha$-amyrin (2b), epi-lupeol (2c), $\beta$-carotene (3) and lutein (4); while the twigs yielded $\mathbf{1 a - 1} \mathbf{b}$. The dichloromethane extracts of the fruits of $C$. ovatum yielded triacylglycerols (5); the mesocarp also afforded 1a, 1b, 1,2-dioleylglycerol (6), and monounsaturated and saturated fatty acids; the nutshell also provided $\mathbf{6}$; and the kernel also yielded monounsaturated and saturated fatty acids. The structures of 1-6 and the fatty acids were identified by comparison of their ${ }^{1} \mathrm{H}$ and/or ${ }^{13} \mathrm{C}$ NMR data with those reported in the literature.
\end{abstract}

\section{INTRODUCTION}

Canarium ovatum Engl. of the family Burseraceae and locally known as pili is indigenous to the Philippines (Brown, 1954). It is the most important nut producing tree in the Philippines (Coronel, 1996) where the roasted or candied nuts are sold commercially (Pili, 2014). The young shoots are edible, while the green pulp can be pickled (Pili, 2014). The oil from the pulp is used for cooking and lighting (Brown, 1954). The tree is also used as lumber and fuel (Coronel, 1996). The C. ovatum resin is employed as an ointment for healing wounds and as a plaster, while raw nuts are used as purgative (Canarium ovatum, 2014). The roasted and unroasted pili nut oil scavenged DPPH radicals by $24.66 \%$ and $9.52 \%$, respectively at a concentration of $140 \mu \mathrm{g} / \mathrm{mL}$ (Zarinah et al., 2014). A recent study reported that the

\footnotetext{
* Corresponding Author

Consolacion Y. Ragasa, Chemistry Department,

De La Salle University, 2401 Taft Avenue, Manila 1004, Philippines.

Email: consolacion.ragasa@dlsu.edu.ph
}

methanol extract of Canarium ovatum resin afforded eighteen known terpenoids consisting of four sesquiterpenes, cryptomeridiol, 4-epicryptomeridiol, eudesm-4(15)-ene-1 $\beta, 11$-diol, cadin-1(14)ene-7 $\beta, 11$-diol and fourteen tritepenes, $\alpha$-amyrin, 3 -epi- $\alpha$-amyrin, brein, 3-epibrein, uvaol, $\beta$-amyrin, 3-epi- $\beta$-amyrin, maniladiol, 3 epimaniladiol, lupeol, 3-oxotirucallic acid, 3 $\alpha$-hydroxytirucallic acid, $3 \beta$-hydroxytirucallic acid, and $3 \alpha$-hydroxytirucalla-7,24-dien21-oic acid. Three of the sesquiterpenes exhibited inhibitory effects on melanin production with $27.4-34.1$ and 39.0-56.9\% reduction of melanin content at 50 and $100 \mu \mathrm{M}$, respectively (Kikuchiet al., 2012). An earlier study reported that gas chromatography (GC) and reversed phase-high pressure liquid chromatography (RP-HPLC) of C. ovatum oil yielded polyunsaturated fatty acids (18:2 and 18:3) which were less than $11 \%$, whereas palmitic acid (16:0) and stearic acid (18:0) were 33.3 and 10.9\%, respectively. Triacylglycerol analysis showed that the high-melting fraction from pili nut oil consisted of POP, POS and SOS+SSO $(\mathrm{P}=$ palmitic acid, $\mathrm{O}=$ oleic acid, and $\mathrm{S}=$ stearic acid) in the proportion of $48.6,38.8$, and $8.7 \%$, respectively (Kakuda et al., 2000). 
This study is part of our research on the chemical constituents of Canarium species found in the hilippines. We earlier reported the isolation of a mixture of new triterpene diastereomers, asperol $\mathrm{a}$ and asperol $\mathrm{b}$, and the major triterpene constituents, $\beta$-amyrin and $\alpha$-amyrin from Canarium asperum resin (Ragasa et al., 2014a). We report herein the isolation from the dichloromethane extracts of the leaves of $C$. ovatum of a mixture of $\beta$-amyrin (1a) and $\alpha$-amyrin (1b) in a 1:3 ratio, another mixture of epi- $\beta$-amyrin (2a), epi- $\alpha$-amyrin (2b) and epi-lupeol (2c) in a 2:1:0.5 ratio, $\beta$-carotene (3) and lutein (4), while the twigs yielded a mixture of $\mathbf{1 a}$ and $\mathbf{1 b}$ in a $1: 2$ ratio. The dichloromethane extracts of the nuts and pulp of $C$. ovatum yielded triacylglycerols (5); the mesocarp also afforded 1a, 1b, 1,2-dioleylglycerol (6) (Fig. 1) and a mixture of monounsaturated and saturated fatty acids in a 3:2 ratio; the nutshell also provided 6; and the kernel also yielded a mixture of monounsaturated and saturated fatty acid

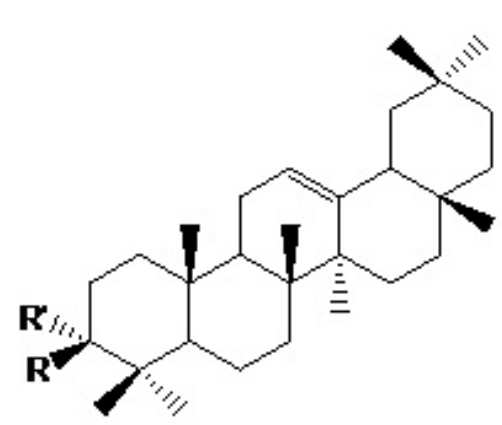

la $\mathbf{R}=\mathbf{O H}, \mathbf{R}^{\prime}=\mathbf{H}$ 2. $\mathbf{R}=\mathbf{H}, \mathbf{R}^{\prime}=\mathbf{O H}$

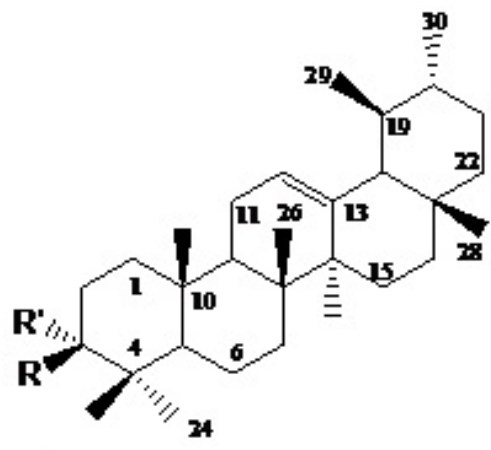

Il $\mathbf{R}=\mathbf{O H}, \mathbf{R}^{\prime}=\mathbf{H}$

2. $\mathbf{R}=\mathbf{H}, \mathbf{R}^{\prime}=\mathbf{O H}$

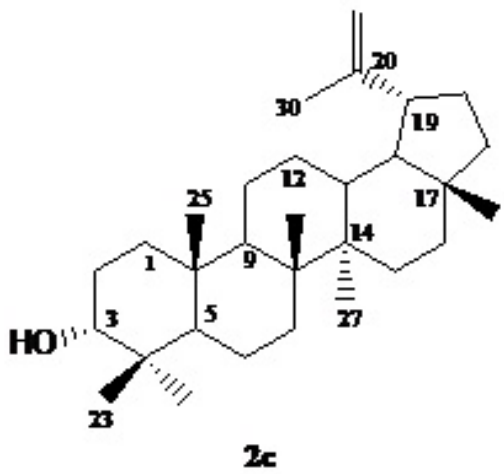<smiles>CC1=C(/C=C/C(C)=C/C=C/C(C)=C/C=C/C=C(C)/C=C/C=C(C)/C=C/C2=C(C)CCCC2(C)C)C(C)(C)CCC1</smiles>

3<smiles>CC1=C[C@@H](O)CC(C)(C)C1/C=C/C(C)=C/C=C/C(C)=C/C=C/C=C(C)/C=C/C=C(C)/C=C/C1=C(C)C[C@@H](O)CC1(C)C</smiles>

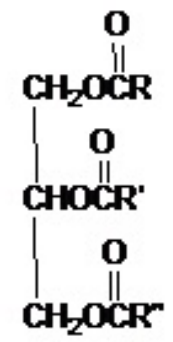

$5 \mathbf{R}, \mathbf{R}^{\prime}, \mathbf{R}^{*}=$ long chain fatty arids

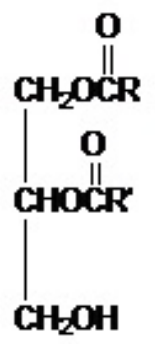

G $\mathbf{R}, \mathbf{R}^{\prime}=$ long chain fatty arid

Fig. 1: Chemical consitituents of Canarium ovatum $\beta$-amyrin (1a), $\alpha$-amyrin (1b), epi- $\beta$-amyrin (2a), epi- $\alpha$-amyrin (2b) and epi-lupeol (2c), $\beta$-carotene (3), lutein (4), triacylglycerols (5), 1,2-diacylglycerol (6). 
in a 2:1 ratio. To the best of our knowledge this is the first report on the chemical constituents of the leaves, twigs and fruits of $C$. ovatum. Previous studies were conducted on the chemical constituents of the oil (Kakuda et al., 2000) and methanol extract of the resin (Kikuchi et al., 2012) of C. ovatum.

\section{General Experimental Procedure}

NMR spectra were recorded on a Varian VNMRS spectrometer in $\mathrm{CDCl}_{3}$ at $500 \mathrm{MHz}$ for ${ }^{1} \mathrm{H}$ NMR; and $125 \mathrm{MHz}$ for ${ }^{13} \mathrm{C}$ NMR spectra. Column chromatography was performed with silica gel 60 (70-230 mesh). Thin layer chromatography was performed with plastic backed plates coated with silica gel $\mathrm{F}_{254}$ and the plates were visualized by spraying with vanillin $/ \mathrm{H}_{2} \mathrm{SO}_{4}$ solution followed by warming.

\section{General Isolation Procedure}

A glass column 20 inches in height and 2.0 inches internal diameter was packed with silica gel. The crude extracts were fractionated by silica gel chromatography using increasing proportions of acetone in dichloromethane ( $10 \%$ increment) as eluents.

One hundred milliliter fractions were collected. All fractions were monitored by thin layer chromatography. Fractions with spots of the same $R_{f}$ values were combined and rechromatographed in appropriate solvent systems until TLC pure isolates were obtained. A glass column 12 inches in height and 0.5 inch internal diameter was used for the rechromatography. Five milliliter fractions were collected. Final purifications were conducted using Pasteur pipettes as columns. One milliliter fractions were collected.

\section{Sample collection and preparation}

The leaves and stems of Canarium ovatum were collected from the De La Salle University-Manila campus in July 2012. The fruit sample was collected from the province of Camarines Norte, Philippines in September 2012. It was identified as Canarium ovatum Engl. at the Bureau of Plant Industry in San Andres, Malate, Manila, Philippines.

The leaves and stems of $C$. ovatum were air-dried for about two weeks. The whole fruit of $C$. ovatum was separated into mesocarp (thick flesh), nutshell and kernel. The mesocarp and kernel were separately ground in a blender and freeze- dried. The nutshell was ground in a mortar and pestle and air-dried.

\section{Isolation of the chemical constituents of the leaves}

The air-dried leaves $(250 \mathrm{~g})$ was soaked in $\mathrm{CH}_{2} \mathrm{Cl}_{2}$ for three days and then filtered. The filtrate was concentrated under vacuum to afford a crude extract (16 g) which was chromatographed using increasing proportions of acetone in $\mathrm{CH}_{2} \mathrm{Cl}_{2}$ at $10 \%$ increment. The $\mathrm{CH}_{2} \mathrm{Cl}_{2}$ fraction was rechromatographed $(3 \times)$ using petroleum ether to afford $\mathbf{3}(3 \mathrm{mg})$. The $20 \%$ and $30 \%$ acetone in $\mathrm{CH}_{2} \mathrm{Cl}_{2}$ fractions were combined and rechromatographed $(4 \times)$ in $15 \%$ EtOAc in petroleum ether to afford a mixture of 1a-1b (7 $\mathrm{mg})$ and another mixture of $\mathbf{2 a - 2 c}(5$ $\mathrm{mg}$ ) after washing with petroleum ether. The $60 \%$ acetone in $\mathrm{CH}_{2} \mathrm{Cl}_{2}$ fraction was rechromatographed $(5 \times)$ in $\mathrm{Et}_{2} \mathrm{O}: \mathrm{CH}_{3} \mathrm{CN}: \mathrm{CH}_{2} \mathrm{Cl}_{2}(0.5: 0.5: 9$, v/v) to yield 4 (7 mg).

\section{Isolation of the chemical constituents of the twigs}

The air-dried twigs (105 g) was soaked in $\mathrm{CH}_{2} \mathrm{Cl}_{2}$ for three days and then filtered. The filtrate was concentrated under vacuum to afford a crude extract $(1.0 \mathrm{~g})$ which was chromatographed using increasing proportions of acetone in $\mathrm{CH}_{2} \mathrm{Cl}_{2}$ at $10 \%$ increment. The $20 \% \mathrm{CH}_{2} \mathrm{Cl}_{2}$ fraction was rechromatographed (4x) using 5\% EtOAc in petroleum ether to afford a mixture of $\mathbf{1 a}$ and 1b (4 mg) after washing with petroleum ether.

\section{Isolation of the chemical constituents of the kernel}

The freeze-dried kernel ( $190 \mathrm{~g}$ ) was soaked in $\mathrm{CH}_{2} \mathrm{Cl}_{2}$ for three days and then filtered. The filtrate was concentrated under vacuum to afford a crude extract (48 g) which was chromatographed using increasing proportions of acetone in $\mathrm{CH}_{2} \mathrm{Cl}_{2}$ at $10 \%$ increment. The $10 \%$ and $20 \%$ acetone in $\mathrm{CH}_{2} \mathrm{Cl}_{2}$ fractions were combined and rechromatographed $(3 \times)$ using $5 \%$ EtOAc in petroleum ether to afford $5(25 \mathrm{mg})$. The $30 \%$ acetone in $\mathrm{CH}_{2} \mathrm{Cl}_{2}$ fraction was rechromatographed (2x) using $10 \%$ EtOAc in petroleum ether to afford a mixture of monounsaturated and saturated fatty acids $(10 \mathrm{mg})$.

\section{Isolation of the chemical constituents of the nutshell}

The air-dried nutshell (953 g) was soaked in $\mathrm{CH}_{2} \mathrm{Cl}_{2}$ for three days and then filtered. The filtrate was concentrated under vacuum to afford a crude extract (9 g) which was chromatographed using increasing proportions of acetone in $\mathrm{CH}_{2} \mathrm{Cl}_{2}$ at $10 \%$ increment.

The $10 \%$ acetone in $\mathrm{CH}_{2} \mathrm{Cl}_{2}$ fraction was rechromatographed $(4 \times)$ using $5 \%$ EtOAc in petroleum ether to afford 5 (95 mg). The $30 \%$ acetone in $\mathrm{CH}_{2} \mathrm{Cl}_{2}$ fraction was rechromatographed (3×) using $\mathrm{Et}_{2} \mathrm{O}: \mathrm{CH}_{3} \mathrm{CN}: \mathrm{CH}_{2} \mathrm{Cl}_{2}$ $(0.25: 0.25: 9.5, \mathrm{v} / \mathrm{v})$ to yield $6(3 \mathrm{mg})$.

\section{Isolation of the chemical constituents of the mesocarp}

The freeze-dried mesocarp $(707 \mathrm{~g})$ was soaked in $\mathrm{CH}_{2} \mathrm{Cl}_{2}$ for three days and then filtered. The filtrate was concentrated under vacuum to afford a crude extract (27.3 g) which was chromatographed using increasing proportions of acetone in $\mathrm{CH}_{2} \mathrm{Cl}_{2}$ at $10 \%$ increment.

The $10 \%$ and $20 \%$ acetone in $\mathrm{CH}_{2} \mathrm{Cl}_{2}$ fractions were combined and rechromatographed $(2 \times)$ using $5 \%$ EtOAc in petroleum ether to afford $5(75 \mathrm{mg})$. The $20 \%$ acetone in $\mathrm{CH}_{2} \mathrm{Cl}_{2}$ fraction was rechromatographed $(3 \times)$ using $10 \%$ EtOAc in petroleum ether to afford a mixture of monounsaturated and saturated fatty acids $(8 \mathrm{mg})$.

The $30 \%$ acetone in $\mathrm{CH}_{2} \mathrm{Cl}_{2}$ fraction was rechromatographed $(3 \times)$ using $10 \%$ EtOAc in petroleum ether to afford a mixture of monounsaturated and saturated fatty acids (18 
$\mathrm{mg}$ ). The $40 \%$ acetone in $\mathrm{CH}_{2} \mathrm{Cl}_{2}$ fraction was rechromatographed $(4 \times)$ using $15 \%$ EtOAc in petroleum ether to yield $6(9 \mathrm{mg})$.

\section{$\beta$-Amyrin (1a)}

Colorless solid. ${ }^{1} \mathrm{H}$ NMR (500 MHz, CDCl3) $\delta 3.15$ (dd, $J=5.0,11.0 \mathrm{~Hz}, \mathrm{H}-3), 5.16(\mathrm{t}, J=3.5 \mathrm{~Hz}, \mathrm{H}-12), 0.77\left(\mathrm{~s}, \mathrm{CH}_{3^{-}}\right.$ 23), 0.90 (s, $\left.\mathrm{CH}_{3}-24\right), 0.73$ (s, $\left.\mathrm{CH}_{3}-25\right), 0.94$ (s, $\left.\mathrm{CH}_{3}-26\right), \quad 1.16$ (s, $\left.\mathrm{CH}_{3}-27\right), 1.05$ (s, $\left.\mathrm{CH}_{3}-28\right), 0.86$ (s, $\left.\mathrm{CH}_{3}-29\right), 0.78$ (s, $\left.\mathrm{CH}_{3}-30\right)$.

\section{$\alpha$-Amyrin (1b)}

Colorless solid. ${ }^{1} \mathrm{H}$ NMR (500 MHz, $\left.\mathrm{CDCl}_{3}\right): \delta 3.15(\mathrm{dd}$, $J=5.0,11.0 \mathrm{~Hz}, \mathrm{H}-3), 5.10(\mathrm{t}, J=3.5 \mathrm{~Hz}, \mathrm{H}-12), 0.93\left(\mathrm{~s}, \mathrm{CH}_{3}-\right.$ 23), 0.74 (s, $\left.\mathrm{CH}_{3}-24\right), 0.73$ (s, $\left.\mathrm{CH}_{3}-25\right), 0.89$ (s, $\left.\mathrm{CH}_{3}-26\right), 1.01$ (s, $\left.\mathrm{CH}_{3}-27\right), 0.94$ (s, $\left.\mathrm{CH}_{3}-28\right), 0.85$ (d, $\left.J=6.0 \mathrm{~Hz}, \mathrm{CH}_{3}-29\right), 0.74$ (d, $J$ $\left.=7.0 \mathrm{~Hz}, \mathrm{CH}_{3}-30\right)$.

\section{epi- $\beta$-Amyrin (2a)}

Colorless solid. ${ }^{1} \mathrm{H}$ NMR $\left(500 \mathrm{MHz}, \mathrm{CDCl}_{3}\right)$ : $\delta$ $5.16(1 \mathrm{H}, \mathrm{t}, J=4.2 \mathrm{~Hz}, \mathrm{H}-12), 3.39$ (1H, br s, H-3), $\quad$ 0.78-0.99 $\left(18 \mathrm{H}, \mathrm{m}, 6 \times \mathrm{CH}_{3}\right), 1.07\left(3 \mathrm{H}, \mathrm{s}, \mathrm{CH}_{3}\right)$ and $1.20\left(3 \mathrm{H}, \mathrm{s}, \mathrm{CH}_{3}\right)$.

\section{epi-a-Amyrin (2b)}

Colorless solid. ${ }^{1} \mathrm{H}$ NMR (500 MHz, $\left.\mathrm{CDCl}_{3}\right): \delta 5.10(1 \mathrm{H}$, $\mathrm{t}, J=4.2, \mathrm{H}-12), 3.39$ (1H, br s, H-3), 0.78-0.99 (21H, m, $\left.7 \mathrm{x} \mathrm{CH}_{3}\right)$ and $1.07\left(3 \mathrm{H}, \mathrm{s}, \mathrm{CH}_{3}\right)$.

\section{epi-Lupeol (2c)}

Colorless solid. ${ }^{1} \mathrm{H}$ NMR (500 $\left.\mathrm{MHz}, \mathrm{CDCl}_{3}\right)$ : $\delta$ 4.67, 4.55 (each $1 \mathrm{H}$, br s, $\left.\mathrm{H}_{2}-29\right), 3.37$ (1H, t, $\left.J=3.0 \mathrm{~Hz}, \mathrm{H}-3 \beta\right), 2.28$ (1H, m, H-19), 1.66 (3H, s, Me-30), 1.01 (3H, s, Me-26), 0.95 (3H, s, Me-23), 0.93 (3H, s, Me-27), 0.84 (3H, s, Me-25), 0.82 (3H, s, Me-28), 0.78 (3H, s, Me-24).

\section{$\beta$-Carotene (3)}

Red orange crystals. ${ }^{1} \mathrm{H}$ NMR $\left(500 \mathrm{MHz}, \mathrm{CDCl}_{3}\right): \delta$ 6.09-6.62 (CH=), $1.03\left(12 \mathrm{H}, \mathrm{s}, \mathrm{CH}_{3}\right), 1.95\left(12 \mathrm{H}\right.$, s, allylic $\left.\mathrm{CH}_{3}\right)$, $1.70\left(6 \mathrm{H}, \mathrm{s}\right.$, allylic $\left.\mathrm{CH}_{3}\right)$.

\section{Lutein (4)}

Orange crystals. ${ }^{1} \mathrm{H}$ NMR $\left(500 \mathrm{MHz}, \mathrm{CDCl}_{3}\right): \delta 1.05(\mathrm{~s}$, 2 ring $\mathrm{A} \mathrm{CH}_{3}$ ), 0.83 (s, ring $\mathrm{B} \mathrm{CH}_{3}$ ), 0.98 (s, ring $\mathrm{B} \mathrm{CH}_{3}$ ), 1.60 (allylic $\mathrm{CH}_{3}$ ), 1.71 (allylic $\mathrm{CH}_{3}$ ), 1.89 (allylic $\mathrm{CH}_{3}$ ), 1.951 (allylic $\left.\mathrm{CH}_{3}\right), 1.944$ (2 allylic $\left.\mathrm{CH}_{3}\right), 1.45,1.75\left(\mathrm{CH}_{2}\right), 1.35,1.85\left(\mathrm{CH}_{2}\right)$, 2.35, 2.00 (allylic $\mathrm{CH}_{2}$ ), 2.38 (allylic $\mathrm{CH}$ ), 4.23 (br s, $\mathrm{CHOH}$ ), 3.98 $(\mathrm{m}, \mathrm{CHOH}), 5.52($ br s, $=\mathrm{CH}), 5.41(\mathrm{dd}, J=9.5,15.5 \mathrm{~Hz},=\mathrm{CH})$, $6.56-6.65,6.33$ (dd, $J=18,3.6 \mathrm{~Hz}), 6.23$ (br d, $J=12 \mathrm{~Hz}), 6.09$ $6.14(=\mathrm{CH})$.

\section{Triacylglycerols (5)}

Colorless oil. ${ }^{1} \mathrm{H}$ NMR (500 MHz, $\left.\mathrm{CDCl}_{3}\right): \delta 4.27(2 \mathrm{H}$, $\mathrm{dd}, J=4.5,12.0 \mathrm{~Hz}$, glyceryl $\left.\mathrm{CH}_{2} \mathrm{O}\right), 4.12(2 \mathrm{H}, \mathrm{dd}, J=6.0,11.5$ $\mathrm{Hz}$, glyceryl $\left.\mathrm{CH}_{2} \mathrm{O}\right), 5.24(1 \mathrm{H}, \mathrm{m}$, glyceryl $\mathrm{CHO}), 2.31(6 \mathrm{H}, \mathrm{t}, J=$
$3.5 \mathrm{~Hz}, \alpha-\mathrm{CH}_{2}$ ), 5.32 (m, olefinic $\mathrm{H}$ ), 2.74 (double allylic $\mathrm{CH}_{2}$ ), 1.97-2.03 (allylic, $\left.\mathrm{CH}_{2}\right), 1.23-1.33\left(\mathrm{CH}_{2}\right), 0.86\left(\mathrm{t}, J=6.5 \mathrm{~Hz}, \mathrm{CH}_{3}\right)$.

\section{1,2-Dioleylglycerol (6)}

Colorless oil. ${ }^{1} \mathrm{H}$ NMR $\left(500 \mathrm{MHz}, \mathrm{CDCl}_{3}\right): \delta 5.33(4 \mathrm{H}$, m), $5.06(1 \mathrm{H}, \mathrm{m}$, glyceryl CHO), $4.28(1 \mathrm{H}, \mathrm{dd}, J=4.5,11.5 \mathrm{~Hz}$, glyceryl $\left.\mathrm{CH}_{2} \mathrm{O}\right), 4.12\left(1 \mathrm{H}, \mathrm{dd}, J=5.5,12.0 \mathrm{~Hz}\right.$, glyceryl $\left.\mathrm{CH}_{2} \mathrm{O}\right)$, $3.71\left(2 \mathrm{H}\right.$, brs, glyceryl $\left.\mathrm{CH}_{2} \mathrm{OH}\right), 2.32\left(\mathrm{t}, J=6.0 \mathrm{~Hz}, \alpha-\mathrm{CH}_{2}\right), 1.97-$ 2.04 (allylic $\left.\mathrm{CH}_{2}\right), 1.60\left(\mathrm{~m}, \beta-\mathrm{CH}_{2}\right), 1.22-1.28\left(\mathrm{CH}_{2}\right), 0.86(\mathrm{t}, J=$ $\left.6.0 \mathrm{~Hz}, \mathrm{CH}_{3}\right) ;{ }^{13} \mathrm{C} \mathrm{NMR}\left(125 \mathrm{MHz}, \mathrm{CDCl}_{3}\right): \delta 173.1,172.8$, 130.03 (C-9), 129.69 (C-10), 72.10 (glyceryl CHO), 61.96 (glyceryl $\mathrm{CH}_{2} \mathrm{OH}$ ), 61.55 (glyceryl $\mathrm{CH}_{2} \mathrm{O}$ ), 34.26, 34.10, 34.08, $31.91,31.90,29.78,29.69,29.65,29.61,29.52,29.46,29.35$, $29.31,29.26,29.22,29.17,29.10,29.08,29.05,27.21,27.16$, 24.91, 24.88, 24.86, 22.67, $22.65\left(\mathrm{CH}_{2}\right), 14.11$ (terminal $\left.\mathrm{CH}_{3}\right)$.

\section{Monounsaturated fatty acid}

Colorless oil. ${ }^{1} \mathrm{H}$ NMR (500 MHz, $\left.\mathrm{CDCl}_{3}\right): \delta 5.33(\mathrm{~m}$, $=\mathrm{CH}), 2.33\left(\mathrm{t}, J=7.5 \mathrm{~Hz}, \alpha-\mathrm{CH}_{2}\right), 1.97-2.01\left(\mathrm{~m}\right.$, allylic $\left.\mathrm{CH}_{2}\right), 1.60$ (m, $\left.\beta-\mathrm{CH}_{2}\right), 1.24-1.32\left(\mathrm{CH}_{2}\right), 0.86(\mathrm{t}, J=6.0 \mathrm{~Hz})$.

\section{Saturated fatty acid}

Colorless oil. ${ }^{1} \mathrm{H}$ NMR (500 MHz, $\left.\mathrm{CDCl}_{3}\right): \delta 2.33(\mathrm{t}, J=$ $\left.7.5 \mathrm{~Hz}, \alpha-\mathrm{CH}_{2}\right), 1.60\left(\mathrm{~m}, \beta-\mathrm{CH}_{2}\right), 1.24-1.32\left(\mathrm{CH}_{2}\right), 0.86(\mathrm{t}, J=6.0$ $\mathrm{Hz})$.

\section{RESULTS AND DISCUSSION}

Silica gel chromatography of the dichloromethane extracts of the leaves of Canarium ovatum Engl. afforded a mixture of $\beta$-amyrin (1a) (Ragasa et al., 2014c) and $\alpha$-amyrin (1b) (Ragasa et al., 2014c) in a 1:3 ratio, and another mixture of epi- $\beta$ amyrin (2a), epi- $\alpha$-amyrin (2b) (Dekebo et al., 2002) and epilupeol (2c) (Rahman et al., 2007) in a 2:1:0.5 ratio, $\beta$-carotene (Cayme and Ragasa, 2004) (3), and lutein (4) (Ragasa et al., 2014d). The twigs yielded a mixture of $\mathbf{1 a}$ and $\mathbf{1 b}$ in a 1:2 ratio. The 1:3 and 1:2 ratios of $\mathbf{1 a}$ and $\mathbf{1 b}$ from the leaves and twigs, respectively were deduced from the integrations of the ${ }^{1} \mathrm{H}$ NMR resonances for the olefinic protons of $1 \mathrm{a}$ at $\delta 5.22(\mathrm{t}, J=3.6 \mathrm{~Hz})$ and $\mathbf{1 b}$ at $\delta 5.15(\mathrm{t}, J=3.6 \mathrm{~Hz})$. The 2:1:0.5 ratio of $\mathbf{2 a}, \mathbf{2 b}$ and $\mathbf{2 c}$ was deduced from the integrations of the ${ }^{1} \mathrm{H}$ NMR resonances for the olefinic protons of $\mathbf{2 a}$ at $\delta 5.28(\mathrm{t}, J=3.6 \mathrm{~Hz}), \mathbf{2 b}$ at $\delta 5.24(\mathrm{t}, J$ $=3.6 \mathrm{~Hz}$ ) and $2 \mathrm{c}$ at $\delta 4.67$ (br s) and 4.55 (br s).

Silica gel chromatography of the dichloromethane extracts of the kernel, nutshell, mesocarp and endocarp of Canarium ovatum Engl. yielded triacylglycerols (5) (Ragasa et al., 2013). Based on the integrations of the triacylglycerol (5) protons in the nutshell, the fatty acids attached to the glycerol are oleic acid (Human Metabolome, 2014b), linoleic acid (Human Metabolome, 2014a) and saturated fatty acid, possibly palmitic acid (Human Metabolome, 2014c). Oleic acid, linoleic acid and palmitic acid were reported as major constituents of $C$. ovatum oil (Kakuda et al., 2000). Based on the integrations of the 
triacylglycerol (5) protons in the mesocarp and kernel, the fatty acids attached to the glycerol are oleic acid $(2 x)$ and palmitic acid. The mesocarp also yielded 1,2-diacylglycerol (6) (Vlahov, 1999; Ragasa et al., 2005) and a mixture of monounsaturated and saturated fatty acid. The fatty acid esterified to the 1,2diacylglycerol (5) is oleic acid (Human Metabolome, 2014b) as deduced from the integrations of the ${ }^{1} \mathrm{H}$ NMR resonances of the olefinic protons at $\delta 5.33$, the allylic protons at $\delta 1.97-2.04$, the $\alpha$ methylene protons at $\delta 2.32$ and the terminal methyl protons at $\delta$ 0.86 . Thus, $\mathbf{6}$ is 1,2 -dioleylglycerol which was confirmed by comparison of its ${ }^{13} \mathrm{C}$ NMR data with literature data (Vlahov, 1999). Compound 6 was also obtained from the nutshell. The 3:2 ratio of the monounsaturated and saturated fatty acids obtained from the mesocarp was deduced from the integrations of the olefinic acid proton resonances at $\delta 5.33$, the allylic protons at $\delta$ 2.0 , the $\alpha$-methylene protons at $\delta 2.30$ and the terminal methyl protons at $\delta 0.87$ for the monounsaturated fatty acid and the $\alpha$ methylene protons at $\delta 2.30$ and the terminal methyl protons at $\delta$ 0.87 for the saturated fatty acid. The monounsaturated fatty acid is possibly oleic acid, while the saturated fatty acid is possibly palmitic acid. Both fatty acids were reported as major constituents of $C$. ovatum oil (Kakuda et al., 2000). The kernel also afforded oleic acid and palmitic acid in a 2:1 ratio.

Although no biological activity tests were conducted on the isolated compounds (1-6 and fatty acids), literature search revealed that these have diverse biological activities as follows.

$\beta$-Amyrin (1a) and $\alpha$-amyrin (1b) were reported to possess anti-inflammatory (Recio et al., 1995; Madeiros et al., 2007; Okoye et al., 2014) and analgesic (Otuki et al., 2005; Soldi et al., 2008) properties. $\beta$-Amyrin showed antifungal activity against A. rabiei with an MIC value of $0.0156 \mathrm{mg} / \mathrm{mL}$ (Jabeen et al., 2011). $\alpha$-Amyrin was proposed as a possible biomarker for the fungal resistance of grape-vine leaves (Vitis vinifera) (Batovska et al., 2008). The mixture of $\mathbf{1 a}$ and $\mathbf{1 b}$ effectively reduced the elevated plasma glucose levels during the oral glucose tolerance test (OGTT). Furthermore, the mixture of $\mathbf{1 a}$ and $\mathbf{1 b}$ at $100 \mathrm{mg} / \mathrm{kg}$ significantly decreased the VLDL and LDL cholesterol and increased the HDL cholesterol (Santos et al., 2012). A review on the sources and biological activities of $\mathbf{1 a}$ and $\mathbf{1 b}$ has been provided (Vasquez et al., 2012).

Epi- $\beta$-amyrin (2a) was reported to inhibit Mycobacterium tuberculosis growth (MIC $=12.2 \mu \mathrm{g} / \mathrm{mL}$ ) and showed cytotoxicity against Vero cells $\left(\mathrm{IC}_{50}=127.2 \mu \mathrm{g} / \mathrm{mL}\right.$ ) (Woldemichael et al., 2004). Triterpene 2a inhibited the cell growth of UACC-62 (human melanoma cancer), MCF-7 (human breast cancer) and TK10 (human renal cancer) by $50 \%$ with $\mathrm{GI}_{50}=>200,128 \pm 29,>200$, respectively (Cota et al., 2007). Triterpene 2a was reported to exhibit stimulatory effect on the root growth of amaranth at 50\% stimulatory concentration $\left(\mathrm{SC}_{50}\right)$ of $5.1 \times 10^{-4} \mathrm{M}$, while it showed root growth inhibitory effect at $50 \%$ inhibitory concentration $\left(\mathrm{IC}_{50}\right)$ of $7.30 \times 10^{-4} \mathrm{M}$ for barnyard grass and $8.72 \times 10^{-4} \mathrm{M}$ for tomato (Macías-Rubalcava et al., 2007).

Lupeol and epilupeol (2c) showed antifungal activity against Fusarium oxysporum and Penicillium notatum (Manzano et al., 2013). Another study reported that $\mathbf{2 c}$ and epilupeol acetate showed pronounced antiviral activity against Ranikhet disease virus (RDV) in chick embryo (Chowdhury et al., 1990). Triterpene 2c showed significant activity against CEM-SS Qmman Tlymphoblastic leukemia cancer cells using MTT assay with an $\mathrm{IC}_{50}$ value of $6.1 \pm 0.20 \mu \mathrm{g} / \mathrm{mL}$ (Mustahil et al., 2013). Another study reported that $2 \mathrm{c}$ exhibited antitubercular activity against Mycobacterium tuberculosis strain $\mathrm{H}_{37} \mathrm{Rv}$ using the Microplate Alamar Blue Assay with a minimum inhibitory concentration (MIC) of $4 \mu \mathrm{g} / \mathrm{mL}$ (Akihisa et al., 2005).

$\beta$-Carotene (3) dose-dependently induced apoptosis and cell differentiation in cultured leukemia cells, but not in normal cells (Upadhyaya et al., 2007). Another study reported that $\beta$ carotene could reduce damage caused by radiation therapy and decrease local cancer recurrence (Meyer et al., 2007). It also inhibited angiogenesis by altering the cytokine profile and the activation and nuclear translocation of transcription factors (Guruvayoorappan and Kuttan, 2007).

Dietary lutein (4), especially at $0.002 \%$, inhibited tumor growth by selectively modulating apoptosis, and by inhibiting angiogenesis (Chew et al., 2003). Another study reported that the chemopreventive properties of all-trans retinoic acid and lutein may be attributed to their differential effects on apoptosis pathways in normal versus transformed mammary cells (Sumatran et al., 2000). Moreover, very low amounts of dietary lutein $(0.002 \%)$ can efficiently decrease mammary tumor development and growth in mice (Park et al., 1998). Another study reported that lutein and zeaxanthine reduces the risk of age related macular degeneration (SanGiovanni, 2007). Triacylglycerols (5) exhibited antimicrobial activity against $S$. aureus, $P$. aeruginosa, B. subtilis, C. albicans, and T. mentagrophytes (Ragasa et al., 2013). Another study reported that triglycerides showed a direct relationship between toxicity and increasing unsaturation, which in turn correlated with increasing susceptibility to oxidation (Ferruzzi and Blakeslee, 2007). sn-1,2-Diacylglycerols (6) modulate vital biochemical mechanisms since they function as second messengers in many cellular processes (Christie, 2013). Another study reported that the directed migration of leukocytes can be stimulated by 1,2-diacylglycerol (Wright et al., 1988).

Linoleic acid belongs to the omega- 6 fatty acids. It was reported to be a strong anticarcinogen in a number of animal models. It reduces risk of colon and breast cancer (Chan et al., 2002) and lowers cardiovascular disease risk and inflammations (Whelan, 2008). A recent study reported that oleic acid, a monounsaturated fatty acid inhibited cancer cell growth and survival in gastric carcinoma SGC7901 and breast carcinoma MCF-7 cell lines (Li et al., 2014). Another study demonstrated that oleic acid promotes apoptotic cell death of breast cancer cells (Menendez et al., 2005). It was also shown to be effective at depressing lipogenesis and cholesterologenesis (Natali et al., 2007). Furthermore, it may contribute to the prevention of atherogenesis (Carluccio et al., 1999). Monounsaturated fatty acids were reported to lower total and LDL cholesterol levels, increase HDL cholesterol levels and decrease plasma triglyceride levels 
(Kris-Etherton, 1999). Palmitic acid, a saturated fatty acid showed selective cytotoxicity to human leukemic cells, induced apoptosis in the human leukemic cell line MOLT-4 and exhibited in vivo antitumor activity in mice (Harada et al., 2002).

\section{CONCLUSION}

The leaves of $C$. ovatum afforded triterpenes and carotenoids; the twigs yielded triterpenes; and the fruits gave diacylglycerol, fatty acids and triacylglycerols with varying fatty acid compositions. The compounds obtained from the leaves, twigs and fruits of $C$. ovatum were reported to exhibit diverse biological activities.

\section{ACKNOWLEDGMENT}

A research grant from the De La Salle University Science Foundation through the University Research Coordination Office is gratefully acknowledged.

\section{REFERENCES}

Akihisa T, Franzblau SG, Ukiya M, Okuda H, Zhang F, Yasukawa K, Suzuki T, Kimura Y. Antitubercular activity of triterpenoids from Asteraceae flowers. Biol Pharm Bull 2005; 28(1):158-160.

Batovska DI, Todorova IT, Nedelcheva DV, Parushev SP, Atanassov AJ, Hvarleva TD, Djakova GJ, Bankova VS. Preliminary study on biomarkers for the fangal resitence in Vitis vinifera leaves. J Plant Physiol 2008; 165:791-795.

Brown WH. 1954. Useful Plants of the Philippines. Rep. Philipp. Dep. Agric. Nat. Res. Tech. Bull. 10(2):241-256. Bureau of Printing, Manila.

Canarium ovatum- World Agroforestry Centre. www.worldagroforestry.org/Canarium_ova... Downloaded on December 27,2014

Carluccio MA, Massaro M, Bonfrate C, Siculella L, Maffia M, Nicolardi G, Distante A, Storelli C, De Caterina R. Oleic acid inhibits endothelial activation: A direct vascular antiatherogenic mechanism of a nutritional component in the mediterranean diet. Arterioscler Thromb Vasc Biol 1999; 19:220-228.

Cayme J-MC, Ragasa CY. Structure elucidation of stigmasterol and $\beta$-sitosterol from Sesbania grandiflora Linn. Pers. and $\beta$-carotene from Heliotropium indicum Linn. by NMR spectroscopy. Kimika. 2004, 20(1/2):5-12.

Chew BP, Brown CM, Park JS, Mixter PF. Dietary lutein inhibits mouse mammary tumor growth by regulating angiogenesis and apoptosis. Anticancer Res 2003; 23(4): 3333-3339.

Chowdhury BL, Hussaini FA, Shoeb A. Antiviral constituents from Vicoa indica. Pharm Biol 1990; 28(2):121-124.

Christie WW. The AOCS Library. 2013. Lipid library.aocs.org/Lipids/dg/index.htm. American Oil Chemists' Society. Downloaded on December 28, 2014.

Coronel RE. Pili nut, Canarium ovatum Engl. Promoting the conservation and use of underutilized and neglected crops, 6. Leibniz Institute of Plant Genetics and Crop Plant Research (IPK), Gatersleben, (Germany). 1996; 57 p.

Cota BB, Johann S, Oliveira DM, Siqueira EP, Souza-Fagundes EM, Cisalpino PS, Alves TMA, Zani CL. Biological potential of Stillingia oppositifolia. Rev Bras Farmacogn 2007; 21(1):70-77.

Dekebo A, Dagne E, Gautun OR, Aasen AJ. Triterpenes from the resin of Boswellia neglecta. Bull Chem Soc Ethiop 2002; 16(1):87-90.

Del Fierro RS, Maquilang QMA, Sanjorjo RAS, Tradio MD, Shen C-C, Ragasa CY. Secondary metabolites from Cinnamomum cebuense. J Med Plants Res 2012; 6(11):2146-2149.
Ferruzzi MG, Blakeslee J. Digestion, absorption, and cancer preventative activity of dietary chlorophyll derivatives. Nutr Res 2007; 27:1-12.

Guruvayoorappan C, Kuttan G. Beta-carotene inhibits tumorspecific angiogenesis by altering the cytokine profile and inhibits the nuclear translocation of transcription factors in $\mathrm{B} 16 \mathrm{~F}-10$ melanoma cells. Integr Cancer Ther 2007; 6(3):258-70.

Harada H, Yamashita U, Kurihara H, Fukushi E, Kawabata J, Kamei Y. Antitumor activity of palmitic acid found as a selective cytotoxic substance in a marine red alga. Anticancer Res 2002; 22(5):2587-90.

Human Metabolome Database. Linoleic acid. Downloaded from http://www.hmdb.ca/spectra/nmr_one_d/1471 on December 28, 2014a.

Human Metabolome Database. Oleic acid. Downloaded from http://www.hmdb.ca/spectra/nmr_one_d/1190 on December 28, 2014b.

Human Metabolome Database. Palmitic acid. Downloaded from http://www.hmdb.ca/spectra/nmr_one_d/00220 on December 28, 2014c.

Jabeen K, Javaid A, Ahmad E, Athar M.. Antifungal compounds from Melia azederach leaves for management of Ascochyta rabiei, the cause of chickpea blight. Nat Prod Res 2011; 25(3):264-276.

Kakuda Y, Jahaniaval F, Marcone MF, Montevirgen L, Montevirgen Q, Umali J. Characterization of pili nut (Canarium ovatum) oil: Fatty acid and triacylglycerol composition and physicochemical properties. J Amer Oil Chem Soc 2000; 77(9):991-997.

Kikuchi T, Watanabe TK, Tochigi Y, Yamamoto A, Fukatsu M, Ezaki Y, Tanaka R, Akihisa T. Melanogenesis inhibitory activity of sesquiterpenes from Canarium ovatum resin in mouse B16 melanoma cells. Chem Biodiver 2012; 9:1500-1507.

Kris-Etherton PM. Monounsaturated fatty acids and risk of cardiovascular disease. Circulation 1999; 100:1253-1258.

Li S, Zhou T, Li C, Dai Z, Che D, Yao Y, Li L, Ma J, Yang X, Gao G. High metastatic gastric and breast cancer cells consume oleic acid in an AMPK dependent manner. PLoS ONE 2014; 9(5): e97330. doi:10.1371/journal.pone.0097330.

Lin JC, Park JH, Budesinsky M, Kasal A, Han YH, Koo BS, Lee SI, Lee BU. Antimutagenic constituents from the thorns of Gleditsia sinensis. Chem Pharm Bull 2005; 53(5):561-564.

Macías-Rubalcava ML, Hernández-Bautista BE, JiménezEstrada M, Cruz-Ortega R, Anaya AL. Pentacyclic Triterpenes with Selective Bioactivity from Sebastiania adenophora Leaves, Euphorbiaceae. J Chem Ecol 2007; 33:147-156.

Madeiros R, Otuki MF, Avellar MC, Calixto JB. 2007. Mechanisms underlying the inhibitory actions of the pentacyclic triterpene-amyrin in the mouse skin inflammation induced by phorbol ester 12-otetradecanoylphorbol-13-acetate. Eur J Pharmacol 55(9):227235.

Manzano PI, Miranda M, Abreu-Payrol J, Silva M, Sterner O, Peralta EL. Pentacyclic triterpenoids with antimicrobial activity from the leaves of Vernonanthura patens (Asteraceae). Emir J Food Agric 2013; 25 (7):539-543

Menendez JA, Vellon L, Colomer R, Lupu R. Oleic acid, the main monounsaturated fatty acid of olive oil, suppresses Her-2/neu (erbB2) expression and synergistically enhances the growth inhibitory effects of trastuzumab (Herceptin) in breast cancer cells with Her-2/neu oncogene amplification. Ann Oncol. 2005; 16(3):359-71.

Meyer F, Bairati I, Jobin E, Gélinas M, Fortin A, Nabid A, Têtu B. Acute adverse effects of radiation therapy and local recurrence in relation to dietary and plasma beta carotene and alpha tocopherol in head and neck cancer patients. Nutr Cancer 2007; 59(1):29-35.

Miyake Y, Yokomizo K, Matsuzaki N. Rapid determination of iodine value by ${ }^{1} \mathrm{H}$ nuclear magnetic resonance spectroscopy. J Am Oil Chem Soc 1998; 75:15-19.

Mustahil NA, Riyanto S, Sukari MA, Rahmani M, Mohd nor SM, Ali AM. Antileukemic activity of extracts and constituents of Aegle marmelos. Res J Chem Environ 2013; 17(1):62-67.

Natali F, Siculella L, Salvati S, Gnoni GV. Oleic acid is a potent inhibitor of fatty acid and cholesterol synthesis in C6 glioma cells. J Lipid Res 2007; 48(9):1966-75. 
Okoye NN, Ajaghaku DL, Okeke HN, Ilodigwe EE, Nworu CS, Okoye FBC. beta-Amyrin and alpha-amyrin acetate isolated from the stem bark of Alstonia boonei display profound anti-inflammatory activity. Pharm Biol 2014; 52(11):1478-1486.

Otuki C, Ferreira J, Lima F, Meyre-Silva C, Malheiros A, Muller L, Cani G, Santos A, Yunes R, Calixto J. Antinociceptive properties of a mixture of $\alpha$-amyrin and $\beta$-amyrin triterpenes: evidence for participation of protein kinase $\mathrm{C}$ and protein kinase A pathways. $\mathrm{J}$ Pharmacol Exp Therapeutics 2005; 31(1):310-318.

Park JS, Chew BP, Wong TS. Dietary Lutein from Marigold Extract Inhibits Mammary Tumor Development in BALB/c Mice. J Nutr 1998; 128(10):1650-1656.

Pili /

I Canarium ovatum

StuartXchange.www.stuartxchange.com/Pili.html. Downloaded on December 26, 2014.

Ragasa CY, Hofileña JG, Co AL, Rideout JA. Antifungal diacetylglycerols from Malachra fasciata and Pithecolobium dulce. ACGC Chem Res Commun 2005; 19:1-5.

Ragasa CY, Lorena GS, Mandia EH, Raga DD, Shen C-C. Chemical constituents of Abrus precatorius. Amer J Essent Oils Nat Prod 2013; 1(2):7-10.

Ragasa CY, Torres OB, Raga DD, Mandia EH, Don M-J, Shen C-C. New triterpenes from the bark of Canarium asperum. Der Pharmacia Lettre 2014a; 6(3):290-294.

Ragasa CY, Caro JL, Lirio LG, Shen C-C. Chemical constituents of Coixlacryma-jobi. Res J Pharm Biol Chem Sci 2014b; 5(6):344-348.

Ragasa CY, Caro JL, Shen C-C. Triterpenes and sterol from Artocarpus ovatus. J Appl Pharm Sci 2014c; 4(10):7-11.

Ragasa CY, Torres OB, Mandia EH, Shen C-C. Chemical constituents of Terminalia microcarpa. Der Pharmacia Lettre 2014d, 6(6):439-442.

Rahman MZ, Sultana SJ, Faruquee CF, Ferdous F, Rahman MS, Islam MS, Rashid MA. Phytochemical and biological investigations of Erythrina variegate. Saudi Pharm J 2007; 15(2):140-145.

Recio MC, Giner RM, Manez S, Rios JL. Structural requirements for the anti-inflammatory activity of natural triterpenoids. Planta Med 1995; 61(2):181-185.

SanGiovanni JP, Chew EY, Clemons TE, The relationship of dietary carotenoid and vitamin $\mathrm{A}, \mathrm{E}$, and $\mathrm{C}$ intake with age-related macular degeneration in a case-control study: AREDS Report No. 22. Arch Ophthalmol 2007; 125(9):1225-1232.

Santos FA, Frota JT, Arruda BR, de Melo TS, de Carvalho AA, da Silva A, Brito GAdC, Chaves MH, Rao VS. Antihyperglycemic and hypolipidemic effects of $\alpha, \beta$-amyrin, a triterpenoid mixture from Protium heptaphyllum in mice. Lipids in Health and Disease 2012; 11:98.
Soldi C, Pizzolatti G, Luiz A, Marcon R, Meotti F, Miotob L, Santos A. Synthetic derivatives of the $\alpha$ - and $\beta$-amyrin triterpenes and their antinociceptive properties. Bioorg Med Chem 2008; 16(6):33773386.

Sumantran VN, Zhang R, Lee DS, Wicha MS. Differential regulation of apoptosis in normal versus transformed mammary epithelium by lutein and retinoic acid. Cancer Epidemiol Biomarkers Prev 2000; 9:257-263.

Upadhyaya KR, Radha KS, Madhyastha HK. Cell cycle regulation and induction of apoptosis by beta-carotene in U937 and HL-60 leukemia cells. J Biochem Mol Biol 2007; 40(6):1009-1015.

Vázquez LH, Palazon J, Navarro-Ocaña A. (2012). The pentacyclic triterpenes, $\alpha, \beta$-amyrins: A review of sources and biological activities, Phytochemicals - A Global Perspective of Their Role in Nutrition and Health, Rao V (Ed.), ISBN: 978-953-51-0296-0, InTech, Available from: http://www.intechopen.com/books/phytochemicals-aglobal-perspective-of-their-role-in-nutrition-and-health/the-pentacyclictriterpenes-amyrins-a-review-of-sources-and-biological-activities.

Vlahov G. Application of NMR to the study of olive oils. Progr Nucl Mag Res Spec 1999; 35: 341-357.

Whelan J. The health implications of changing linoleic acid intakes. Prostaglandins, Leukot Essent Fatty Acids 2008; 79(3-5):165-167.

Woldemichael GM, Gutierrez-Lugo MT, Franzblau SG, Wang Y, Suarez E, Timmermann BN 2004. Mycobacterium tuberculosis growth inhibition by constituents of Sapium haematospermum. J Nat Prod 2004; 67:598-603.

Wright TM, Hoffman RD, Nishijima J, Jakoi L, Snyderman R, Shin HS. Leukocyte chemo attraction by 1,2-diacylglycerol. Proc Natl Acad Sci USA 1988; 85:1869-1873.

Zarinah Z, Maaruf AG, Nazaruddin R, Wong WWW, Xuebing $X$. Antioxidant, antimicrobial activity and in-vitro cytotoxicity screening study of Pili nut oil. Intl Food Res J 2014; 21(1): 309-316.

\section{How to cite this article:}

Consolacion Y. Ragasa, Oscar B. Torres, Chien-Chang Shen. Triterpenes and Acylglycerols from Canarium ovatum. J App Pharm Sci, 2015; 5 (04): 094-100. 